\title{
Carotenoid Pigments from Suspended and Sinking Particulate Matter in Prydz Bay, Antarctica
}

\author{
Il $\mathrm{Noh}^{*}$ \\ Division of Marine Environment \& Bioscience, Korea Maritime University, Busan 606-791, Korea \\ (Manuscript received 23 May, 2011; revised 1 July, 2011; accepted 19 October, 2011)
}

\begin{abstract}
Suspended and sinking particles were collected during ODP Leg 119 to the Indian Ocean sector of the Antarctic Ocean. Field work was carried out at four sampling sites in Prydz Bay. Two of these sites were located in the Outer Bay, and two in the Inner Bay. At the four locations, a total of ten deployments of a sediment trap array were made. The concentrations of carotenoids both in suspended and sinking particulate matter in Prydz Bay were analyzed using HPLC. Fucoxanthin was the dominant carotenoid pigments both in suspended and sinking particles. The present study also indicates that 19'-hexanoyoxyfucoxanthin-containing prymesiophytes (Phaeocystis spp.) was abundant in the study area. The flux rates of carotenoids were generally highest at $50 \mathrm{~m}$, and approximately double the flux rates at deeper horizons, however, at Inner Bay sites, the mean flux rates of carotenoids were greatest at $200 \mathrm{~m}$, and 3 times greater than that of $50 \mathrm{~m}$. Such anomalous high fluxes at $200 \mathrm{~m}$ imply that grazers were locally abundant between $100 \mathrm{~m}$ and $200 \mathrm{~m}$ at these sites close to land, and this hypothesis is supported by visual evidence of lots of fecal pellets in the $200 \mathrm{~m}$ trap. Integrates standing stocks versus sinking pigments data support that particulate material in Prydz Bay was not recycled rapidly.
\end{abstract}

Key Words : Carotenoids, Prydz Bay, Sediment trap, Flux, Integrated standing stock, HPLC

\section{Introduction}

Despite intense interest among scientists from a variety of disciplines in the processes that drive the production, distribution and transport of particulate organic matter in the oceans, we still have but limited quantitative data on how much and what kind of biogenic particulate organic matter escapes from the surface waters of the Southern Ocean.

It is now generally agreed that the dominant mechanism for the vertical transport of organic matter into the deep sea is the relatively rapid settling of large particles (McCave, 1975), which recent

${ }^{*}$ Corresponding author : Il Noh, Division of Marine Environment \& Bioscience, Korea Maritime University, Busan 606-791, Korea

Phone: +82-51-410-4327

E-mail: ilnoh@hhu.ac.kr studies have shown is dominated by "marine snow", and other uncompacted aggregates, as well as by compact fecal pellets and fecal strings. Such particles are ubiquitous in the oceans (Urrere and Knauer, 1981) and they are involved in many chemical and biological processes (Brewer et al., 1980; Deuser and Ross, 1980; Karl et al., 1984; Knauer et al., 1982; Rowe and Gardner, 1979). In general, the amount of organic material escaping from the euphotic zone increases as a function of primary production (Eppley and Peterson, 1979), while particulate organic carbon (POC) residence times decrease (Eppley et al., 1983). A number of sediment trap studies have confirmed that a strong predictive relationship between primary production rates and the particle flux out of the euphotic zone exists for areas that are widely separated geographically (Deuser et al., 1981; Honjo, 
1982; Suess, 1980). Consequently, there is a continuing need for accurate, direct measurements of the flux of particulate organic matter out of the euphotic zone, to see whether this has global predictive value, as we seek to more fully understand upper ocean biological processes.

The present research focused on the measurement of photosynthetic carotenoid pigments in suspended and sinking particles collected from Southern Ocean surface waters during austral summer 1987-1988. Participation in Ocean Drilling Program (ODP) Leg 119 allowed us to investigate short-term (day-to-day) variations in particle flux, and to see how these compared in different locations of the Indian Ocean sector of the Antarctic Ocean during the course of the same austral summer.

This study will report the pigment composition of suspended versus sinking particulate material. Our two data sets allow a more complete understanding of how pigment flux varies in response to local phytoplankton blooms, to proximity to ice edges, and to other environmental parameters that varied on a day-to-day scale at each of the sampling locations.

Both spatial and temporal variations of algal pigments in marine environments should correlate strongly with the physico-chemical variations in the upper water column, since phytoplankton abundance is regulated by nitrate flux, pycnocline location, and by vertical stability of water column (Marra et al., 1982; Parsons et al., 1981; Seliger et al., 1981). Important biological processes which in turn modify phytoplankton abundance are phytoplankton production, cellular senescence, cell sinking and zooplankton gazing (Bidigare et al., 1986; Welschmeyer and Lorenzen, 1985).

The Southern Ocean is characterized by high nutrient concentrations, marked seasonal variations in irradiance, low water temperatures, and comparatively little near-surface density stratification, which facilitates frequent mixing (Holm-Hansen, 1985; Tilzer et al.,
1986). Phytoplankton biomass and productivity in Antarctic waters are highly variable (El-Sayed, 1968; El-Sayed and Turner, 1977; Fogg, 1977; HolmHansen et al., 1977). Previous Studies have shown that localized physical processes were the important factors in phytoplankton biomass accumulations in Southern Oceans (El-Sayed and Taguchi, 1981; Jennings et al., 1984; Marra and Boardman, 1984; Smith and Nelson, 1985). However, the specific factors controlling the distribution of Antarctic phytoplankton on broader spatial and temporal scales have not been fully resolved (Allanson et al., 1981; El-Sayed and Weber, 1982; Hayes et al., 1984).

Although it is well recognized that: 1) there is a positive functional relationship between primary production and the downward flux of particulate organic matter and 2) the degree of this relationship depends strongly on trophic interactions that take place in the euphotic zone (Eppley and Peterson, 1979), the amount of production that is recycled versus exported from surface waters of the Southern Ocean is still incompletely understood. In particular, detailed knowledge regarding the flux rates of photosynthetic pigments from the near-surface mixed layer and the degree to which individual compounds are remineralized as a function of depth is an area of active research. Because we now suspect that large particle production plays a central role in water column biogeochemistry, upper ocean sediment trap studies can serve to allow clearer insights into the time scales over which new production and sinking are coupled in Southern Ocean. Moreover, since such research integrates geochemical processes with biological processes, it represents a useful first step in unraveling the complex interplay of oceanographic factors which influence particulate transport and sedimentation in the Southern Ocean.

For Prydz Bay, several null hypotheses $\left(\mathrm{H}_{\mathrm{o}}\right)$ can be tested:

1) there are no local differences in the average 
concentration of the principal suspended algal pigments between Outer Prydz Bay sites and Inner Bay sites;

2) there are no local differences in the average fluxes of sinking algal pigments between Outer Prydz Bay sites and Inner Bay sites;

3) the ratio of the total sinking algal pigments to the standing stock in the upper water column in Prydz Bay is evidence for a rapid turnover of the standing stocks.

\section{Materials and methods}

\subsection{Field collections}

Suspended and sinking particles were collected in January-February 1988 during ODP Leg 119 to the Indian Ocean sector of the Antarctic Ocean (Fig. 1). The field work was carried out at four sampling sites in Prydz Bay. Two of these sites were located in the Outer Bay, and two in the Inner Bay. At the four locations, a total of ten deployments of a sediment trap array were made.

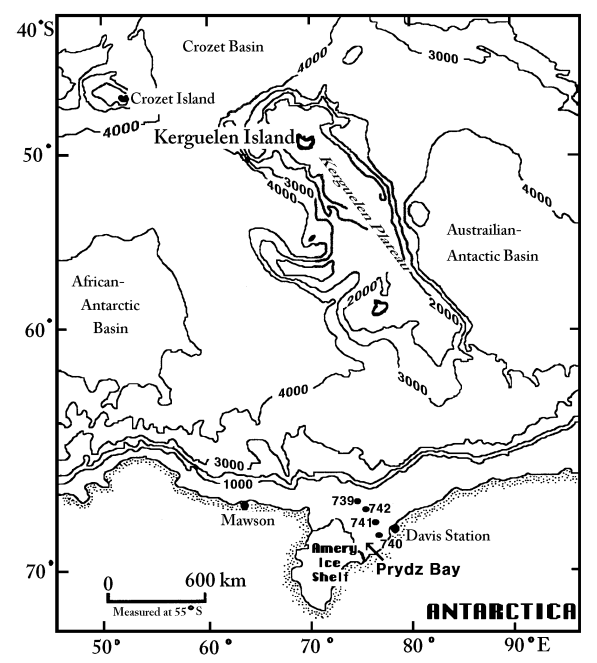

Fig. 1. Floating sediment traps (FSTs) were deployed in Outer Prydz Bay (Sites 739, 742) and Inner Bay (Sites 740, 741) during Ocean Drilling Program (ODP) Leg 119 in Jan-Feb, 88.

\subsection{Description of sediment traps}

Sinking particulate matter was collected with conical sediment traps (Fig. 2) that were designed and fabricated by Dr. R. B. Dunbar of Rice University (Dunbar, 1984).

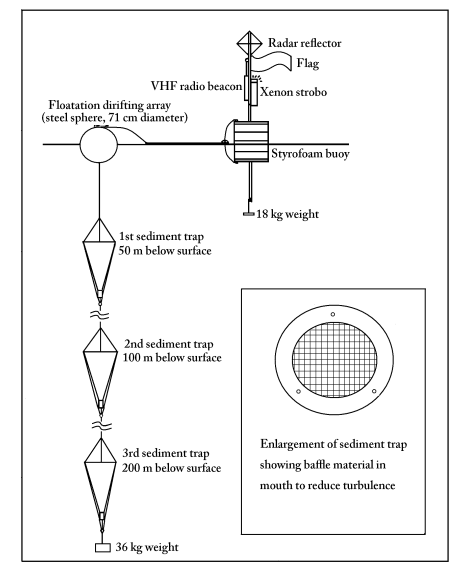

Fig. 2. Floating sediment trap drift array used for Prydz Bay collections.

These traps were deployed on a drifting array which had three sediment traps suspended on braided nylon mooring line below a primary flotation sphere. To this sphere, a tracking buoy was tethered, which was outfitted with radio beacon, flashing strobe, radar reflector and flag. The radio beacon (Novatech, Model RF 700B), which broadcast at a VHF frequency of $156 \mathrm{MHz}$, could be tracked at least 6-7 miles away from the ship on channel 68 of a commercial RDF unit. After 20-37 hours, as weather allowed and/or depending on the drift rate of the arrays and the tending duties of the ice escort vessel, arrays were recovered and redeployed.

Dr. Dunbar's sediment traps are similar to those built by Andy Soutar (Scripps Institution of Oceanography) and used in an intercalibration experiment in the Santa Barbara basin in 1979 (Dymond et al., 1981). Following that intercalibration experiment, the Soutar trap was chosen as the simplest, most reliable 
sediment trap for the collection of large samples. The funnelling effects of the conical geometry preconcentrates its sample, and this non-closing trap is easy to service and then redeploy.

Made of gel-coated fiberglass, Dunbar traps weigh only about 8 kilograms. Valved holes in the sides of the cone allow most of the water overlying the collection chamber to be drained off prior to hauling each trap on board, and with a simple manual block and tackle rig one can get a multiple trap array back aboard easily.

Dunbar traps have a collecting cross section of $1600 \mathrm{~cm}^{2}$. The baffle material used in the traps is an impregnated nylon honeycomb mesh with cells $1 \mathrm{~cm}$ wide by $4 \mathrm{~cm}$ deep.

Laboratory flume studies indicate that a baffle with these dimensions prevents the penetration of turbulent eddies into the trapping chamber (Dymond et al., 1981). Our experience on Leg 119 confirmed this, for material in the cod-end chamber was not visibly resuspended back into the cone, even when the trap was surging near surface during recoveries in seas of 1-2 meters.

\subsection{Collection depths and sample processing}

The shallow trap collected sinking material at 50 $\mathrm{m}$, close to the base of the mixed layer; the two additional traps collected from the upper pycnocline, at $100 \mathrm{~m}$ and at $200 \mathrm{~m}$.

Based on collections made during Leg 113 in the Weddell Sea, it was anticipated that drifting traps in Prydz Bay would intercept between 0.1 and $1 \mathrm{gm} \mathrm{m}^{-2}$ day $^{-1}$.

Accordingly, it was planned that enough material would be trapped in 24 hours so that each collection could be split into fourths (or eighths) to give an archive aliquot, as well as 3 or more working aliquots for analysis of plant pigments and other substances. The archive aliquot was preserved in $4 \%$ buffered formaldehyde for analysis of particle morphology and for phytoplankton enumerization and taxonomy. The remaining aliquots were used for plant pigments and their degradation products: aliquots were filtered onto Nuclepore $0.4 \mu \mathrm{m}$ polyester filters $(47 \mathrm{~mm}$ ). These filters were then frozen for post-cruise analysis.

\subsection{Sampling with CTD and Niskin bottles}

To determine the temperature-salinity and calculated density characteristics and depth of the mixed layer at each site where traps were deployed, the upper $200 \mathrm{~m}$ of the water column were profiled with an internalrecording Seabird SBE-19 "Sea Cat" CTD (conductivitytemperature-depth) system. Light penetration was determined using a Secchi disc at each site where traps were deployed and the euphotic zone (EZ), a depth corresponding to $1 \%$ of light intensity at the surface, was obtained using the following formula (1) (Evans et al., 1987).

$$
\mathrm{EZ}(\mathrm{m})=\ln \frac{1}{100} \times \frac{\text { Secchi disc meters }(\text { Ds })}{-1.7}
$$

Five-liter capacity Niskin bottles were used to collect water samples for analysis of suspended particles at six depths, generally 10, 30, 50, 75, 100 and $200 \mathrm{~m}$.

\subsection{Analysis of carotenoid pigments}

For HPLC pigment analysis, filters frozen at sea were transported frozen on "blue ice" in an insulated chest. The samples were processed 2-6 weeks after the cruise, at Texas A\&M University, as follows;

The filters were individually ground (glass/glass homogenizer) in $2 \mathrm{ml}$ of $90 \%$ acetone, allowed to extract for 48 hours, and centrifuged to remove suspended particles. In order to separate the dephytolated pigments, ion-pairing solution was added to the sample prior to injection into the HPLC system (Mantoura and Llewellyn, 1983).

Following the methods of Bidigare et al. (1985), 
algal pigments were separated with an HPLC system consisting of two Varian Model 2510 isocratic pumps, Model 2584 static mixer and a sample injector (Rheodyne Model 7125, $500 \mu$ l sample loop). A reverse-phase Microsorb $\mathrm{C}_{18}$ column $(10 \mathrm{~cm}$ bed $\mathrm{L}$ x $4.6 \mathrm{~mm} \mathrm{ID,} 3 \mu \mathrm{m}$ particle size, Rainin Co.) was used for the pigment analysis, fitted with a guard column $(1.5 \mathrm{~cm}$ bed L x $4.6 \mathrm{~mm}$ ID, $3 \mu \mathrm{m}$ particle size, Rainin Co.).

A gradient solvent system (solvent A of 80:15:5 of methanol:distilled water:IP solution; solvent B of 100 $\%$ methanol) was employed for the elution of algal pigments. Solvent delivery was programmed at 100 $\%$ solvent $\mathrm{A}$ for the initial condition, then a linear gradient to $100 \%$ solvent $\mathrm{B}$ at $2 \mathrm{~min}$, followed by an isocratic hold $(100 \% \mathrm{~B})$ until phaeophytin a peak was eluted (36.5 min). The flow rate was held constant at $1.2 \mathrm{ml} / \mathrm{min}$. Carotenoid peaks were quantified using an absorption detector (Varian, Model 2550 Variable $\lambda$ Detector) at $436 \mathrm{~nm}$. The HPLC was calibrated according to the procedures outlined by Bidigare (1989) and American Public Health Association (1989).

The extinction coefficients used to calculate concentrations by serial dilution are presented as Table 1. Fucoxanthin, diadinoxanthin and diatoxanthin were extracted from Skeletonema costatum batch cultures by TLC, and standards prepared by calibrating spectrophotometrically in $100 \%$ ethanol. Peridinin was extracted from Gymnodinium culture, purified by TLC, and then calibrated spectrophotometrically in
$100 \%$ ethanol.

For identification purposes, 19'-hexanoyloxyfucoxanthin and 19'-butanoyloxyfucoxanthin were extracted from subtropical coccolithophorids and silicoflagellates, respectively, purified by TLC, and then injected into the HPLC system to allow their retention times ( $\mathrm{R} t)$ to be compared with that of fucoxanthin. While all three compounds eluted between 4.6-5.0 minutes, these averaged $4.7 \mathrm{~min}, 4.8 \mathrm{~min}$, and $4.9 \mathrm{~min}$, respectively. In practice, the concentrations of 19'-hexanoyloxyfucoxanthin and 19'-butanoyloxyfucoxanthin in the samples were routinely estimated by using the identical response factor $\left(\mathrm{R}_{f}\right)$ that was used for fucoxanthin, because their absorbance properties are similar to fucoxanthin. Zeaxanthin was extracted from Synechococcus spp., purified by TLC, and calibrated spectrophotometrically in $100 \%$ ethanol. $\beta$-carotene standard was purchased from Sigma Chemical Co., and calibrated spectrophotometrically in $100 \%$ ethanol. Our HPLC methods do not separate zeaxanthin from lutein, for as Bidigare et al. (1985) has pointed out, the two carotenoids pigments coelute with the same retention time of $6.4 \mathrm{~min}$. Thus, zeaxanthin concentrations are probably overestimated in environments when/where green algae (which contain lutein instead of zeaxanthin) are relatively abundant.

The following formula (2) was used to calculate the individual pigment concentrations:

$$
\mathrm{C} i=\mathrm{A} s \times(1 / \mathrm{R}) \times(1 / \mathrm{IV}) \times(\mathrm{EV}) \times(1 / \mathrm{SV})
$$

Table 1. The extinction coefficients $\left(\mathrm{L} \mathrm{g}^{-1} \mathrm{~cm}^{-1}\right)$ used for the calibration of carotenoid standards

\begin{tabular}{|c|c|c|c|c|}
\hline Pigment & $\lambda \max$ & Solvent & Ex & Source \\
\hline fucoxanthin & $449 \mathrm{~nm}$ & EtOH & 160.0 & Jensen, 1966 \\
\hline peridinin & $475 \mathrm{~nm}$ & $\mathrm{EtOH}$ & 132.5 & Jeffrey, 1968 \\
\hline diadinoxanthin & $445 \mathrm{~nm}$ & $\mathrm{EtOH}$ & 262.0 & Goodwin, 1955 \\
\hline diatoxanthin & $449 \mathrm{~nm}$ & $\mathrm{EtOH}$ & 262.0 & Davies, 1976 \\
\hline zeaxanthin & $450 \mathrm{~nm}$ & $\mathrm{EtOH}$ & 254.0 & Davies, 1976 \\
\hline$\beta$-carotene & $449 \mathrm{~nm}$ & $\mathrm{EtOH}$ & 262.0 & Davies, 1976 \\
\hline
\end{tabular}


where,

$\mathrm{C} i=$ individual pigment concentration (ng per liter)

$\mathrm{A} s=$ area of individual pigment peaks computed by Varian 4270 integrator

$\mathrm{R}=$ standard response factor (peak area divided by $\mathrm{ng}$ pigment per $0.5 \mathrm{ml}$ standard)

$\mathrm{IV}=$ injection volume $(0.5 \mathrm{ml})$

$\mathrm{EV}=$ extraction volume (in milliliters)

$\mathrm{SV}=$ sample volume (in liters)

\section{Results}

\subsection{Water column structure in Prydz Bay}

Distribution of salinity (Practical Salinity Unit: PSU) and temperature $\left({ }^{\circ} \mathrm{C}\right)$ measured in Prydz Bay are shown in Fig. 3. Based on $\mathrm{T} / \mathrm{S}$ curve similarities between Sites 739 and 742, we have grouped these as Outer Prydz Bay. Similarly, we have grouped Sites 740 and 741 as Inner Prydz Bay.
Note that temperature in the upper $200 \mathrm{~m}$ at both locations generally varied by only $3{ }^{\circ} \mathrm{C}\left(+1{ }^{\circ} \mathrm{C}\right.$ to -2 ${ }^{\circ} \mathrm{C}$ ) and salinity by only 1 PSU ( 33.5 to 34.5 PSU). However, because temperatures in the upper $50 \mathrm{~m}$ of the Inner Bay ranged from $0{ }^{\circ} \mathrm{C}$ to $+1.5{ }^{\circ} \mathrm{C}$, the near-surface water there was relatively warmer than that at Outer Bay sites. In addition, note that salinity in the Inner Bay generally ranged between 34.0 to 34.5 PSU, with little variation down to $200 \mathrm{~m}$. Thus, Inner Bay sites were relatively saltier throughout the upper $200 \mathrm{~m}$ than were Outer Bay sites, at which salinity in the upper $50 \mathrm{~m}$ reached as low as 33.7 PSU. These facts indicate that the sea ice had melted more recently at Outer Bay sites, which agrees with time-series satellite imagery of the ice cover in Prydz Bay (see Fig. 2 in Biggs et al., 1989). Thus, Inner Bay sites, which were ice-free longer than Outer Bay
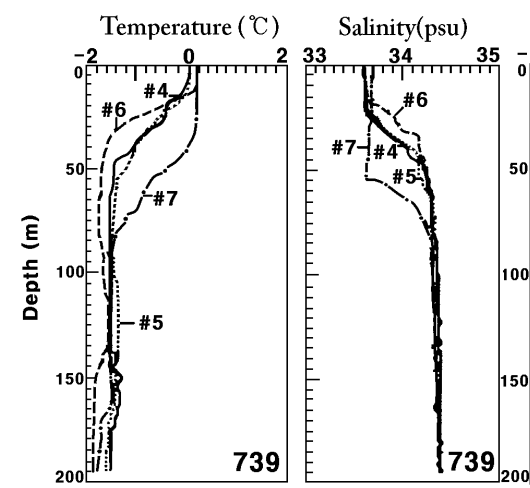

Temperature $\left({ }^{\circ} \mathrm{C}\right)$
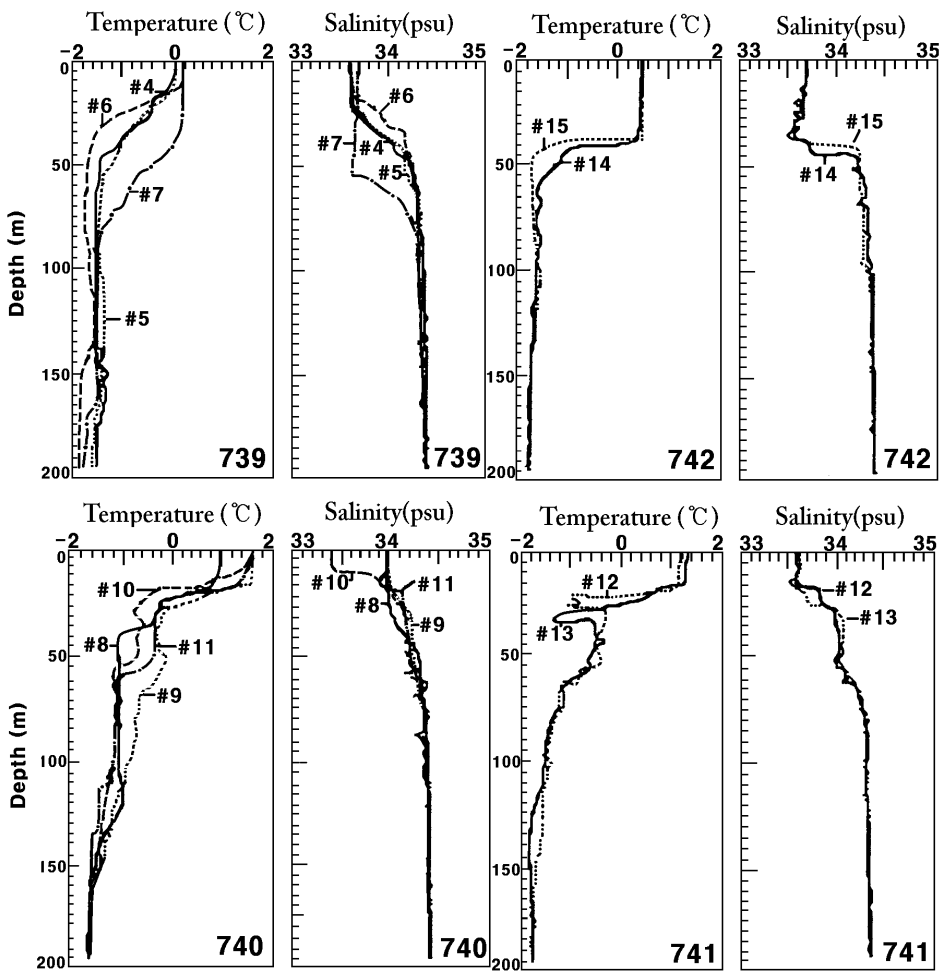

Temperature $\left({ }^{\circ} \mathrm{C}\right)$
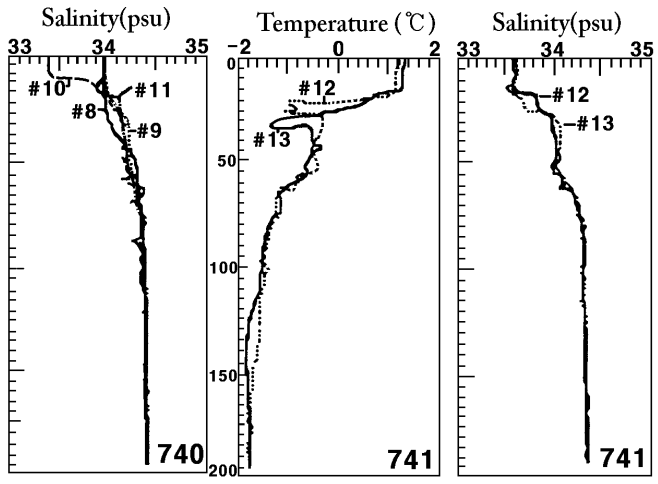

Fig. 3. Temperature and salinity structure of the upper $200 \mathrm{~m}$ of Outer (Sites 739, 742) and Inner Prydz Bay (Sites 740, 741). \# No. denotes the CTD cast number. 
sites, had more time for upper waters to warm.

\subsection{Carotenoid pigment composition of suspended} particulate matter in Inner vs. Outer Prydz Bay

Some general trends can best be seen when sampling sites are grouped into Inner Prydz Bay (740, 741) versus Outer Prydz Bay (739, 742).

At Outer Bay sites, Fucoxanthin, 19'-hexanoyloxyfucoxanthin, peridinin, diadinoxanthin, diatoxanthin, zeaxanthin/lutein and $\beta$-carotene were all detected in the upper $200 \mathrm{~m}$, and most reached maximum concentrations subsurface between 25-75m (Fig. 4). Fucoxanthin was the most abundant of these seven carotenoids, generally ranging from 0.2 to $0.5 \mu \mathrm{g}$ liter $^{-1}$ in the upper $76 \mathrm{~m}$, with average concentration $0.3 \mu \mathrm{g} \operatorname{liter}^{-1}$ (Fig. 4A). The vertical distribution pattern of 19'-hexanoyloxyfucoxanthin (Fig. 4E) was somewhat different. It was not detected in the upper $25 \mathrm{~m}$, but it had a subsurface maximum at $33 \mathrm{~m}$. Below this, concentrations decreased gradually but remained detectable down to $195 \mathrm{~m}$. The concentration of peridinin (Fig. 4B) was rather low (average only a few tens of nanograms per liter) from the surface to $25 \mathrm{~m}$, but it increased in concentration to 0.1 to $0.4 \mu$ $\mathrm{g}_{\text {liter }}^{-1}$ between $25 \mathrm{~m}$ and $75 \mathrm{~m}$.

As at the Outer Bay locations, fucoxanthin, peridinin, 19'-hexanoyloxyfucoxanthin, diadinoxanthin, diatoxanthin, zeaxanthin/lutein and $\beta$-carotene were
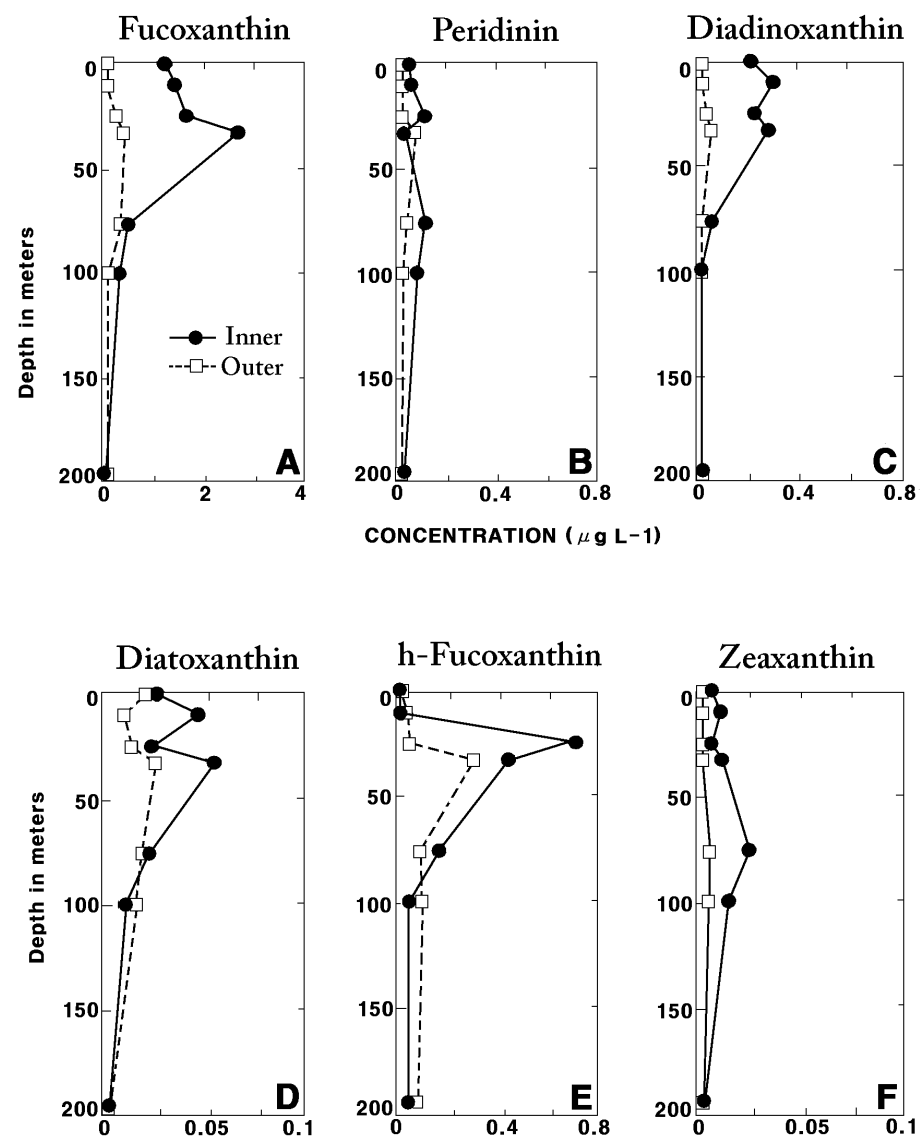

CONCENTRATION ( $\mu \mathrm{g} \mathrm{L}-1)$

Fig. 4. The vertical distributions of carotenoids at Inner versus Outer Prydz Bay sites. Dark circle denotes Inner Prydz Bay; open square, Outer Prydz Bay. 
detected at Inner Prydz Bay location, and fucoxanthin was again the most abundant of these seven carotenoids. The vertical distribution of fucoxanthin (Fig. 4A) showed maximum concentrations at $33 \mathrm{~m}$.

As in Outer Prydz Bay, 19'-hexanoyloxyfucoxanthin (Fig. 4E) was rare in near-surface waters $(<0.002 \mu$ $\left.\mathrm{g} \mathrm{liter}^{-1}\right)$. Detectable levels generally appeared at 25 $\mathrm{m}$ and then decreased again to at or near the limit of detection by $200 \mathrm{~m}$. Peridinin (Fig. 4B), unlike fucoxanthin, had high concentrations as deep as $76 \mathrm{~m}$. The concentration of fucoxanthin at Inner Bay locations was 4-5 times higher than that at Outer Bay locations, and the concentration of peridinin in the Inner Bay averaged 2.4 times higher than that in the Outer Bay. Note, however, that while peridinin in the Outer Bay usually had a subsurface maximum, with highest concentrations at the depths $33 \mathrm{~m}$ and $76 \mathrm{~m}$ (Fig. 4B), in the Inner Bay peridinin showed a bimodal pattern, with a local minimum in concentration at $33 \mathrm{~m}$.

The distribution of diadinoxanthin in Outer versus
Inner Bay (Fig. 4C) showed the similar pattern as fucoxanthin in the Inner versus Outer Bay. Highest concentrations were generally found at $10 \mathrm{~m}, 25 \mathrm{~m}$, and $33 \mathrm{~m}$. Note that the diadinoxanthin concentration in the Inner Bay averaged 4.6 times higher than that in the Outer Bay.

In Inner Prydz Bay, the distribution pattern of diatoxanthin (Fig. 4D) tracked that of diadinoxanthin. In general, the concentration of diatoxanthin at Inner Bay sites averaged 1.5 times that at Outer Bay Sites.

At both Inner and Outer Bay sites, concentration of zeaxanthin/lutein (Fig. 4F) below $25 \mathrm{~m}$ was higher than that in the shallower depths, and Inner Bay sites averaged 4.2 times more zeaxanthin/lutein than Outer Bay sites.

3.3. Integrated standing stock of algal pigments in suspended matter

Table 2 summarize the integrated standing stock of pigments and their degradation products at Inner Bay

Table 2. Integrated standing stocks of suspended pigments $(\mathrm{SS} i)$ in $\mathrm{mg} \mathrm{m}^{-2}$ versus sinking pigments $(\mathrm{F})$ in $\mu \mathrm{g} \mathrm{m}^{-2}$ day $^{-1}$ in Prydz Bay

\begin{tabular}{|c|c|c|c|c|c|c|c|c|c|}
\hline & \multicolumn{2}{|c|}{$0-50 \mathrm{~m}$} & \multirow[b]{2}{*}{$\%$} & \multicolumn{2}{|c|}{$0-100 \mathrm{~m}$} & \multirow[b]{2}{*}{$\%$} & \multicolumn{2}{|c|}{$0-200 \mathrm{~m}$} & \multirow[b]{2}{*}{$\%$} \\
\hline & $\mathrm{SS} i$ & $\mathrm{~F}$ & & $\mathrm{SS} i$ & $\mathrm{~F}$ & & $\mathrm{SS} i$ & $\mathrm{~F}$ & \\
\hline \multicolumn{10}{|l|}{ Inner Bay } \\
\hline Peri $^{1}$ & 2.8 & 0.5 & $<0.1$ & 4.4 & 1.5 & $<0.1$ & 7.1 & 3.8 & $<0.1$ \\
\hline But-fuco $^{2}$ & $\mathrm{ND}^{*}$ & ND & - & ND & ND & - & ND & ND & - \\
\hline Fuco $^{3}$ & 92.5 & 15.1 & $<0.1$ & 151.7 & 22.5 & $<0.1$ & 170.1 & 64.9 & $<0.1$ \\
\hline Hex-fuco $^{4}$ & 7.4 & 4.6 & $<0.1$ & 7.4 & 8.2 & 0.1 & 8.6 & 26.6 & 0.3 \\
\hline Diadino $^{5}$ & 8.3 & 1.0 & $<0.1$ & 20.2 & 1.9 & $<0.1$ & 21.2 & 6.0 & $<0.1$ \\
\hline Diato $^{6}$ & 2.0 & 1.4 & $<0.1$ & 3.2 & 3.0 & 0.1 & 3.7 & 9.4 & 0.3 \\
\hline $\mathrm{Zea}^{7}$ & 0.6 & 0.5 & 0.1 & 1.5 & 1.1 & $<0.1$ & 2.2 & 6.2 & 0.3 \\
\hline$\beta-\mathrm{Car}^{8}$ & 1.0 & 0.5 & $<0.1$ & 1.6 & 0.6 & $<0.1$ & 1.6 & 2.3 & 0.1 \\
\hline \multicolumn{10}{|l|}{ Outer Bay } \\
\hline Peri & 1.4 & 3.8 & $<0.1$ & 3.6 & 5.6 & 0.1 & 5.2 & 6.7 & 0.1 \\
\hline But-fuco & 0.1 & 0.7 & 0.7 & 0.2 & 0.9 & 0.5 & 0.3 & 0.9 & 0.3 \\
\hline Fuco & 12.2 & 10.6 & $<0.1$ & 25.2 & 17.5 & $<0.1$ & 28.6 & 20.8 & $<0.1$ \\
\hline Hex-fuco & 3.7 & 5.7 & 0.1 & 8.1 & 7.7 & $<0.1$ & 13.6 & 8.9 & $<0.1$ \\
\hline Diadino & 1.7 & 2.7 & 0.1 & 2.9 & 4.1 & 0.1 & 3.7 & 4.7 & 0.1 \\
\hline Diato & 0.9 & 0.8 & $<0.1$ & 1.6 & 1.2 & $<0.1$ & 2.3 & 1.5 & $<0.1$ \\
\hline Zea & 0.1 & 1.1 & 1.1 & 0.2 & 1.7 & 0.9 & 0.5 & 1.9 & 0.4 \\
\hline$\beta-\mathrm{Car}$ & 0.1 & 0.3 & 0.3 & 0.2 & 0.6 & 0.3 & 0.2 & 0.8 & 0.4 \\
\hline
\end{tabular}

${ }^{1}:$ peridinin ${ }^{2}: 19^{\prime}$-butanoyloxyfucoxanthin ${ }^{3}:$ fucoxanthin ${ }^{4}: 19^{\prime}$-hexanoyloxyfucoxanthin ${ }^{5}$ :diadinoxanthin ${ }^{6}:$ diatoxanthin ${ }^{7}:$ zeaxanthin $^{8}:$ - carotene $^{*}:$ Not detectable 
sites 740 and 741 and at Outer Bay sites 739 and 742, expressed as $\mathrm{mg} \mathrm{m}^{-2}$. At Inner Bay sites, note the dominance of fucoxanthin. As at the Inner Bay sites, note the dominance of fucoxanthin, and of 19'-hexanoyloxyfucoxanthin, as well. Tables 2 shows that integrated standing stocks of pigment at Inner Bay sites ( $\mathrm{I} i$ ) were 2-9 times higher than those at Outer Bay sites $(\mathrm{O} i)$. The sole exceptions to this $\mathrm{I} i>$ O $i$ trend were 19'-butanoyloxyfucoxanthin. At Inner Bay sites 19'-butanoyloxyfucoxanthin was undetected there.

\subsection{Carotenoid composition of sinking particulate} matter: Collections by floating sediment traps

The mean carotenoid fluxes (Fig. 5) in the Inner Bay were greatest at $200 \mathrm{~m}$ (and usually over 3 times higher than the fluxes at $50 \mathrm{~m}$ and $100 \mathrm{~m}$ ). In contrast, the carotenoid fluxes in Outer Bay were highest at the shallowest depth $(50 \mathrm{~m})$, and the fluxes decreased with increasing depth.

\section{Discussion}

Phytoplankton Community Structure of the Water Column

Carotenoids are commonly used as biomarkers to identify phytoplankton species. Throughout the Prydz Bay bottle cast samples, fucoxanthin were the dominant pigment species among carotenoids. This indicates that the phytoplankton community of the study area was dominated by diatoms a prediction confirmed by
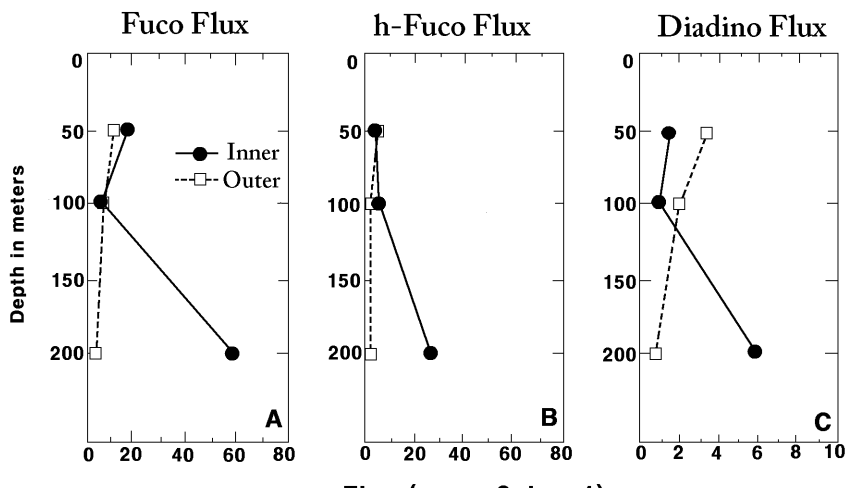

Flux ( $\mu$ g m-2 day-1)
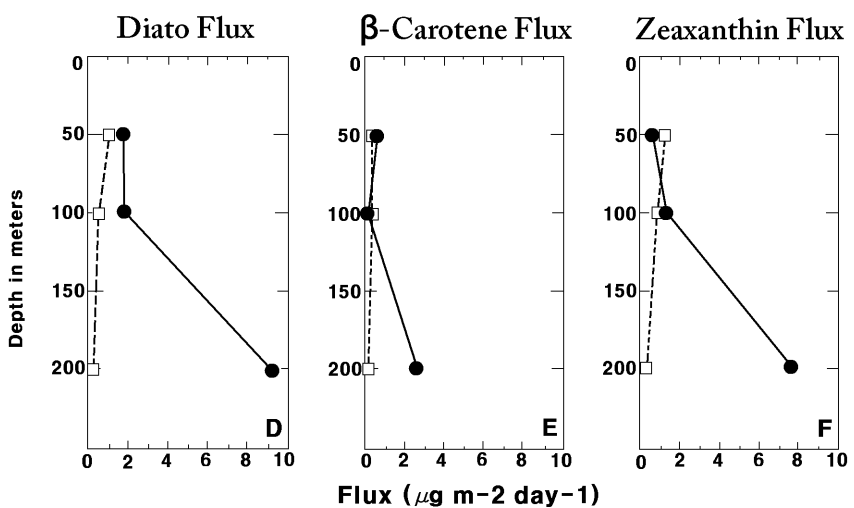

Fig. 5. Mean fluxes of carotenoids in Inner Bay versus Outer Prydz Bay. Dark circle denotes Inner Prydz Bay; open square, Outer Prydz Bay. 
Kang (1989), who by counting phytoplankton numbers in subsamples fixed by Lugols from the same bottle casts that were analyzed by HPLC, found direct evidence of a diatom bloom that was dominated by Nitzschia cylindrus and N. closterium. Moreover, because 19'-hexanoyloxyfucoxanthin was the second most abundant carotenoid, it indicates that prymnesiophytes (e.g. Phaeocystis spp.) were also very abundant in the study area. However, even after they have been fixed in Lugols, Antarctic prymnesiophytes seldom remain intact enough to allow quantitative enumeration.

Three genera of phytoplankton are most commonly reported in large populations and blooms in the Southern Ocean: 1) Phaeocystis Lagerheim, 2) Thalassiosira Cleve, and 3) Nitzschia Hassle.

Fryxell and Kendrick (1988) reported that both Phaeocystis and Thalassiosira dominated the genera in the bloom in open water seaward of the seasonal packice in the Weddell Sea/Scotia Sea. Especially in this respect, the presence of 19'-hexanoyloxyfucoxanthin in relatively high abundance throughout the study area indicates that Phaeocystis spp. likely was abundant here, even though the preserved samples from Prydz Bay were dominated by diatoms. Moreover, the presence of peridinin throughout the study area indicates that the dinoflagellates, as well, contributed to the phytoplankton bloom.

\section{Carotenoid Pigments Distribution of the Water Column}

Temperature-salinity-density structure of the water column strongly influenced the vertical distributions of algal pigments in the study area. Specifically, when the mixed layer depth (MLD) was shallow, it provided favorable conditions for the ambient phytoplankters to bloom.

The base of the euphotic zone (EZ; estimated as the depth of penetration of $1 \%$ of surface irradiance) varied according to the vicinity to the continental land mass. The average EZ depth at the Outer Bay sites was $20 \mathrm{~m}$, approximately twice that at Inner Bay sites, where it ranged from 9-12 m (Fig. 6). It is well known that the availability of light with respect to depth is controlled by attenuation by detritus, phytoplankton, and dissolved substances. However, the light which is attenuated by dissolved matter, which includes "yellow substance", is generally minimal in high productivity areas, where most of light is attenuated by the phytoplankton stocks themselves (Lorenzen, 1976). At the Inner Bay sites, as the phytoplankton bloom proceeded, it is probable that the self-shading effect of phytoplankton limited the depth of $1 \%$ light penetration to a rather uniform 9-12 m.

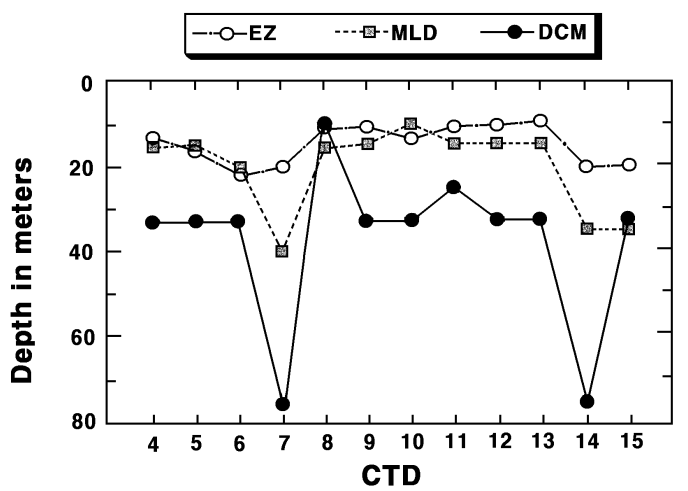

Fig. 6. Relationship between depth of Euphotic Zone (EZ), Mixed Layer (ML), and Deep Chlorophyll Maximum (DCM) in Prydz Bay at stations made on ODP Leg 119. CTD casts \#4, 5, 6, 7 and \#14, 15 at Outer Bay sites 739 and 742, respectively; CTD casts \#8, 9, 10,11 and \#12, 13 at Inner Bay sites 740 and 741 , respectively.

The fact that fucoxanthin was the most abundant of the carotenoids in suspended particulate matter throughout the study area is independent evidence, as stated previously, that the Prydz Bay sites were dominated by diatoms. This is supported by the fact that the accessory pigments present in diatoms (fucoxanthin and diadinoxanthin) were co-abundant 
in most of the samples.

Diadinoxanthin and diatoxanthin, two carotenoids also found in diatoms, were also present in most of the samples. As Stephens (1989) has reported, diatoxanthin shows a tight coupling with diadinoxanthin in vertical distribution [DT:DN xanthophyll cycle; Jeffrey, 1980]. In Prydz Bay, the concentration of diadinoxanthin was approximately twice the concentration of diatoxanthin at most depths in most samples. This ratio of diatoxanthin to diadinoxanthin agrees with that determined by Stephens (1989) (0.4 on average, expressed in mol:mol) in the open water phytoplankton collected at Anvers Island in the austral summer 1987.

Peridinin, which is a chemotaxonomic marker for the dinoflagellates, was generally more common at mid-depths $(76-100 \mathrm{~m})$ than at shallower depths in Prydz Bay. This indicates that dinoflagellates in Prydz Bay generally were more abundant below the DCM. Even though peridinin concentrations were an order of magnitude lower than those of fucoxanthin in most of the samples, however, peridinin was present in almost every water column sample in Prydz Bay. Interestingly, in all casts, peridinin had a local minimum in concentration between $25-75 \mathrm{~m}$. The cause of such a discontinuous distributional pattern of dinoflagellates in Prydz Bay is not known. Whether there may be preferential depth ranges for different types of dinoflagellates in the Southern Ocean needs further investigation.

The carotenoid 19'-hexanoyloxyfucoxanthin, which is a chemotaxonomic marker of pymnesiophytes (e.g. Phaeocystis, as well as the subtropical coccolithophore Emiliania huxleyi), was generally rare above $25 \mathrm{~m}$. Because it was the second most abundant carotenoid (after fucoxanthin) in the zone 25-75 m, if its co-elution with fucoxanthin was not too great, it indicates that the optimum niche for prymnesiophyte populations in Prydz Bay was subsurface, both coincident with and below the deep chlorophyll maximum (DCM)(Noh, 2011). By contrast, 19'- butanoyloxyfucoxanthin was not detectable in most of the study area.

Zeaxanthin, which coeluted with lutein in our HPLC system, is a chemotaxonomic marker of cyanobacteria. Because zeaxanthin is thought to be a photoprotectant for cyanobacteria, its highest concentrations are usually found at or near the surface. However, while cyanobacteria are generally present in the near-surface water of many oceanic environments (Ondrusek, 1989), they have been reported to be less abundant in the surface waters of Southern Ocean (Letelier and Karl, 1989; Marchant et al., 1987). In fact, Marchant et al. (1987) suggested that cold temperatures are the principal factor limiting cyanobacterial abundance in the Southern Ocean. In Prydz Bay, while the overall concentration of zeaxanthin/lutein was low, it generally exhibited a deeper water rather than a near-surface maximum. The most likely explanation for the deeper water presence and near-surface rarity of zeaxanthin/lutein, apart from the obvious conclusion that cyanobacteria were probably rare there, is that prochlorophytes, rather than cyanobacteria, were present. Prochlorophytes contain lutein as their accessory pigment, and while information about their distribution in the Southern Ocean is limited, these nanoplankton have been found in other oceans to be most abundant deeper rather than shallower in the photic zone.

In summary, Inner Bay sites had 3-5 times greater concentrations of suspended algal pigments than at Outer Bay sites. Locally greater water column stability imparted by the local temperature-salinity-density structure was probably the main factor responsible for the bloom conditions within Inner Prydz Bay.

\section{Carotenoids in Material Sinking Out of Prydz Bay}

Sediment trap collections reported by Dunbar (1984) from Bransfield Strait had mass fluxes 5-7 times higher than the highest flux at each site of the 
Prydz Bay areas. Dunbar described that during the summer season of high productivity in Bransfield Strait, the dominant component of the vertical flux of sediment at nearly all depths was fecal pellet material. In contrast, Dunbar reported that fecal pellets were not a very common component of the vertical flux collected from different regions in the Ross Sea. Rather, low-density gelatinous aggregates of organic material and diatom tests were common in the Ross Sea collections, and mass fluxes there were at least 10-fold lower than in his Bransfield collections.

During ODP Leg 113, a drifting sediment trap array of the same type used a year later for the present Prydz Bay work was deployed to investigate the flux of natural particulate materials from Weddell Sea summer surface waters (Biggs, 1988). Mass flux out of the upper $100 \mathrm{~m}$ at Weddell Sea sites averaged $0.16 \mathrm{~g} \mathrm{~m}^{-2}$ day $^{-1}$, and that at $200 \mathrm{~m}$ averaged $0.12 \mathrm{~g}$ $\mathrm{m}^{-2}$ day $^{-1}$. Pigment fluxes at the Outer Prydz Bay sites were generally similar to those trapped during Leg 113 for carotenoids.

Interestingly, the fluxes at $50 \mathrm{~m}$ and $100 \mathrm{~m}$ were not markedly greater at Inner versus Outer Bay sites, even though the mean concentration of suspended algal pigments in Inner Prydz Bay was 3 times higher than that in the Outer Bay. In general, at most of the Prydz Bay sites, the particle flux was greater at $50 \mathrm{~m}$ than at $200 \mathrm{~m}$. For instance, at Outer Bay Sites 739 and 742 , the pigment fluxes at $100 \mathrm{~m}$ were $40-60 \%$ of at $50 \mathrm{~m}$, and the pigment fluxes at $200 \mathrm{~m}$ were $20-30 \%$ of those at $50 \mathrm{~m}$. This presumably reflects both the higher primary production rates in the shallower depth strata, as well as the increasing importance of remineralization between 50-100 m, and between 100-200 m. At Inner Bay Site 741 the flux pattern was similar, with flux greatest at $50 \mathrm{~m}$, intermediate at $100 \mathrm{~m}$, and lowest at $200 \mathrm{~m}$.

However, because of the abundance of fecal pellets at Site 740 , the mean fluxes at $200 \mathrm{~m}$ averaged
6 fold greater than that at $50 \mathrm{~m}$, and an order of magnitude higher than those of Leg 113. Such anomalous high fluxes at $200 \mathrm{~m}$ imply that grazers were locally abundant between $100 \mathrm{~m}$ and $200 \mathrm{~m}$ at these sites close to land, and this hypothesis is supported by visual evidence of lots of fecal pellets in the $200 \mathrm{~m}$ trap.

\section{Inventories of Suspended versus Sinking Materials}

The carotenoiod pigment flux out of the upper $200 \mathrm{~m}$, relative to the integrated standing stock (integrated standing stock in $\mathrm{mg} \mathrm{m}^{-2}$ divided by the flux in $\mu \mathrm{g} \mathrm{m}^{-2}$ day $^{-1}$ ), ranged from 0.1-0.4\% (average $0.3 \%$ ) at Outer Bay Sites; from 0.1-0.3 \% (average 0.1\%) at Inner Bay Sites (see Table 2).

These data do not support the null hypothesis that particulate material in Prydz Bay was recycled rapidly. On the contrary, phytoplankton standing stocks appeared to be very healthy, so that the amount of material settling out of the euphotic zone was also negligible, compared to that produced daily by photosynthesis.

\section{References}

Abaychi, J. K., Riley, J. P., 1979, The determination of phytoplankton pigments by high-performance liquid chromatography, Anal. Chim. Acta, 107, 1-11.

Allanson, B. R., Hart, R. C., Lutjeharms, J. R. E., 1981, Observations on the nutrients, chlorophyll and primary production of the Southern Ocean south of Africa, South African J. Antarctic Res., 10/11, 3-14.

Alldredge, A. L., 1979, The chemical composition of microscopic aggregates in two neritic seas, Limnol. Oceanogr., 254, 855-866.

American Public Health Association, 1989, Highperformance liquid chromatographic determination of algal chlorophylls and their degradation products, in: Standard Methods for the Examination of Water and Wastewater, 17th ed., Washington, D. C., 1039 . 
Barrett, J., Jeffrey, S. W., 1971, A note on the occurrence of chlorophyllase in marine algae, $\mathrm{J}$. Exp. Mar. Biol. Ecol., 7, 255-262.

Bidigare, R. R., 1989, Photosynthetic pigment composition of the brown tide alga: Unique chlorophyll and carotenoid derivatives, in: Cosper, E., Carpenter, E. J. and Bricelj, M. (eds.), Novel Phytoplankton Blooms, Coastal and Estuarine Studies, vol. 35. Springer-Verlag, Berlin, 57-75.

Bidigare, R. R., Kennicutt, M. C., Brooks, J. M., 1985, Rapid determination of chlorophylls and degradation products by high performance liquid chromatography, Limnol. Oceanogr., 30, 432-435.

Bidigare, R. R., Frank, T. J., Zastrow C., Brooks, J. M., 1986, The distribution of algal chlorophylls and their degradation products in the Southern Ocean, Deep-Sea Res., 33, 923-937.

Biggs, D. C., Berkowitz, S. P., Altabet, M. A., Bidigare, R. R., DeMaster, D. J., Dunbar, R. B., Leventer, A. N., Macko, S. A., Nittroluer, C. A., Ondrusek, M. E., 1988, Upper-ocean particulate fluxes in the Weddell Sea, Proc. ODP, Init. Repts., 113, College Station, TX (Ocean Drilling Program), 77-86.

Biggs, D. C., Berkowitz, S. P., Altabet, M. A., Bidigare, R. R., DeMaster, D. J., Macko, S. A., Ondrusek, M. E., Noh, I., 1989, Cooperative study of upper ocean particulate fluxes, Proc. ODP, Init. Repts., 119, 109-120.

Bogdanov, D. V., Sokolov, V. A., Khromov, N. S., 1969, Regions of high biological and commercial productivity in Gulf of Mexico and Caribbean Sea, Oceanology, 8, 371-381.

Brewer, P. G., Nozaki, Y., Spencer, D. W., Fleer, A. P., 1980, Sediment trap experiments in the deep North Atlantic: isotopic and elemental fluxes, J. Mar. Res., 38, 703-728.

Deuser, W. G. Ross, E. H., 1980, Seasonal changes in the flux of organic carbon to the deep Sargasso Sea, Nature, 283, 364-365.

Deuser, W. G., Ross, E. H., Anderson., R. F., 1981, Seasonality in the supply of sediment to the deep Sargasso Sea and implication for the rapid transfer of matter to the deep ocean, Deep-Sea Res., 28, 495-505.

Dugdale, R. C., Goering, J., 1967, Uptake of new and regenerated forms of nitrogen in primary productivity, Limnol. Oceanogr., 12, 196-206.

Dunbar, R. B., 1984, Sediment trap experiments on the Antarctic continental margin, Antarctic J. U. S., Ann. Rev. Iss., 19, 70-71.

Dymond, J., Fisher, K., Clauson, M., Cobler, R., Gardner, W., Berger, W., Richardson, M., Soutar, A., Dunbar, R., 1981, A sediment trap intercomparison study in the Santa Barbara basin, Earth Planet, Sci. Lett., 53, 409-418.

El-Sayed, S. Z., 1968, Primary productivity of the Antarctic and subantarctic, in: Bushnell, V. (ed.), Primary Productivity and Benthic Marine Algae of the Antarctic and Subantarctic, Antarctic Map Folio series, Folio 10, American Geographical Society, New York, 119-135.

El-Sayed, S. Z., 1970, On the productivity of the Southern Ocean (Atlantic and Pacific sectors), in: Holdgate, A. (ed.), Antarctic Ecology, vol. 1, Academic Press, New York, 119-135.

El-Sayed, S. Z., Turner, J. T., 1977, Productivity of the Antarctic and tropical subtropical regions: A comparative study, in: Dunbar, M. J. (ed.), Polar Oceans Arctic Institute of North America, Calgary, Alberta, Canada, 463-504.

El-Sayed, S. Z., Taguchi, S., 1981, Primary production and standing crop of phytoplankton along the ice-edge in the Weddell Sea, Deep-Sea Res., 28A(9), 1017-1032.

El-Sayed, S. Z., Weber, L. H., 1982, Spatial and primary productivity in the southwest Atlantic and the Scotia Sea, Polar Biol., 1, 83-90.

Eppley, R. W., Peterson, B.J., 1979, Particulate organic matter flux and planktonic new production in the deep ocean, Nature, 282, 677-680.

Eppley, R. W., Renger E. H., Betzer P. R., 1983, The residence time of particulate organic carbon in the surface layer of the ocean, Deep-Sea Res., 30, 311-323.

Evans, C. A., O’Reilly, J. E., Thomas, J. P., 1987, A Handbook for the Measurement of Chlorophyll a and Primary Production, BIOMASS Scientific Series No. 8, Texas A\&M Univ., College Station, Texas, 114.

Fogg, G. E., 1977, Aquatic primary production in the 
Antarctic, Phil. Trans R. Soc. Lond. B 279, 27-38.

Gallagher, J. C., Wood, A. M., Alberte, R. S., 1984, Ecotyptic differentiation in the marine diatom Skeletonema costatum: influence of light intensity on the photosynthetic apparatus, Mar. Biol., 82, 121-134.

Hayes, P. K., Whitaker, T. M., Fogg, G. E., 1984, The distribution and nutrient status of phytoplankton in the Southern Ocean between 20 and $70^{\circ} \mathrm{W}$, Polar Biol., 3, 153-165.

Holm-Hansen, O., 1985, Nutrient cycles in Antarctic Marine Ecosystems, in: Siegfried, W. R., Condy, P. R. and Laws, R. M. (eds.), Antarctic Nutrient Cycles and Food Webs, Springer-Verlag, Berlin, 6-10.

Holm-Hansen, O., El-Sayed, S. Z., Franceschini, G. A., Cuhel, R. L., 1977, Primary production and the factors controlling phytoplankton growth in Southern Ocean, in: Llano, G. A. (ed.), Adaptations within Antarctic Ecosystems, Proceedings of the third SCAR Symposium on Antarctic Biology, National Academy of Sciences, Washington, D. C., 11-50.

Honjo, S., 1978, Sedimentation of materials in the Sargasso Sea at a $5367 \mathrm{~m}$ deep station, J. Mar. Res., 36, 469-492.

Honjo, S., 1982, Seasonality and interaction of biogenic and lithogenic particulate flux at the Panama Basin, Science, 218, 883-884.

Jeffrey, S. W., 1968, Quantitative thin-layer chromatography of chlorophylls and carotenoids from marine algae, Biochim. Biophys. Acta, 162, 271-285.

Jeffrey, S. W., 1972, Preparation and some properties of crystalline chlorophyll $\mathrm{c}_{1}$ and $\mathrm{c}_{2}$ from marine algae, Biochim. Biophys. Acta, 279, 15-33.

Jeffrey, S. W., 1974, Profiles of photosynthetic pigments in the ocean using thin-layer chromatography, Mar. Biol., 26, 101-110.

Jeffrey, S. W., 1980, Algal pigment systems, in: Falkowski, P. G. (ed.), Primary productivity in the sea, Plenum, New York. 33-58

Jeffrey, S. W., 1981, An improved thin-layer chromatographic technique for marine phytoplankton pigments, Limnol. Oceanogr., 16, 191-197.

Jeffrey, S. W., Humphrey, G. F., 1975, New spectro- photometric equations for determining chlorophylls $\mathrm{a}, \mathrm{b}, \mathrm{c}_{1}$ and $\mathrm{c}_{2}$ in higher plants, algae and natural phytoplankton, Biochemie und Physiologie der Pflanzen, 167, 191-194.

Jeffrey, S. W., Hallegraeff, G. M., 1980, Studies on phytoplankton species and photosynthetic pigments in a warm core eddy of the East Austrailian Current. I. Summer populations, Mar. Ecol. Prog. Ser., 3, 285-294.

Jennings, J. C., Gordon, L. I., Nelson, D. M., 1984, Nutrient depletion indicates high primary productivity in the Weddell Sea, Nature, 309, 51-54.

Kang, S. H., 1989, Diatom species composition and abundance in water column assemblages from five drill sites in Prydz Bay, Antarctica, Ocean Drilling Program Leg 119: Distributional patterns, M. S. Thesis, Texas A\&M Univers ity, College Station, Texas, USA.

Karl, D. M., Knauer, G. A., Martin, J. H., Ward, B. B., 1984, Chemolithotrophic bacterial production in association with rapid sinking particles: Implication of oceanic carbon cycles and mesopelagic food webs, Nature, 309, 54-56.

Knauer, G. A., Hebel, D., Cippriano, F., 1982, Marine snow: Major site of primary production in coastal waters, Nature, 300, 630-631.

Lorenzen, C. J., 1972, Extinction of light in the ocean by phytoplankton, J. Cons. Int. Explor. Mer., 34, 262-267.

Lorenzen, C. J., 1976, Primary production in the sea, in: Cushing, D. H. and Walsh, J. J. (eds.), Ecology of the Seas, Blackwell Scientific Publications, Oxford, 173-185.

Mantoura, R. F. Llewellyn, C. A., 1983, The rapid determination of algal chlorophyll and carotenoid pigments and their breakdown products in natural waters by reverse-phase high-performance liquid chromatography, Anal. Chim. Acta, 151, 297-314.

Marra, J., Houghton, R. W., Boardman, D. C., Neale, P. J., 1982, Variability in surface chlorophyll a at a shelf break front, J. Mar. Res., 40, 575-591.

Marra, J., Boardman, D. C., 1984, Late winter chlorophyll a distributions in the Weddell sea, Mar. Ecol. Prog. Ser., 19, 197-205.

McCave, I. N., 1975, Vertical flux of particles in the 
ocean, Deep-Sea Res., 22, 491-502.

Noh, I., 2011, Chlrorophylls and their degradation products using High Performance Liquid Chromatography (HPLC), with data from suspended and sinking particulate matter in Prydz Bay, Antarctica, J. Korean Nav. Port Res., 35(4), 323-334.

Parsons, T. R., Stronach, J., Borstad, G. A., Louttit, G., Petty, R. I., 1981, Biological fronts in the Strait of Georgia, British Colombia, Mar. Ecol. Prog. Ser., 6, 237-242.

Rowe, G. T., Gardner, W. D., 1979, Sedimentation rates in the slope water of the northwest Atlantic Ocean measured directly with sediment traps, J. Mar. Res., 37, 581-600.

Sakshaug, E., Holm-Hansen, O., 1984, Factors governing pelagic production in polar oceans, in: Bolis, L. and Gilles, R. (eds.), Marine Phytoplankton and Productivity, Springer-Verlag, Berlin, 1-17.

Seliger, H. H., McKinley, K. R., Biggley, W. H., Rivkin, R. B., Aspden, K. R. H., 1981, Phytoplankton patchiness and frontal regions, Mar. Biol., 61, 119-131.

Shanks, A. L., Trent, J. D., 1979, Marine Snow: Microscale nutrient patches, Limnol. Oceanogr., 24, 850-854.

Silver, M. W., Shanks, A. L., Trent, J. D., 1978, Marine snow: microplankton habitat and sources of small-scale patchiness in pelagic populations, Science, 201, 371-373.

Smith, W. O. Jr., Nelson, D. M., 1985, Phytoplankton bloom produced by a receding ice edge in the Ross Sea: Spatial coherence with the density field, Science, 227, 163-166.

Steele, J. H., 1962, Environmental control of photosynthesis in the sea, Limnol. Oceanogr., 7, 137-150.

Stephens, F. C., 1989, Effects of ultraviolet light on photosynthesis and pigments of Antarctic marine phytoplankton, Ph. D. Dissertation, Texas A\&M
University, College Station, Texas, USA.

Strickland, J. D. H., Parsons, T. R., 1972, A Practical Handbook of Seawater Analysis, Fish. Res. Board Can. Bull., 167, 2nd ed., Ottawa, Canada.

Suess, E., 1980, Particulate organic carbon flux in the oceans: surface productivity and oxygen utilization, Nature, 288, 260-263.

Tilzer, M. M., von Bodungen, B., Smetacek, V., 1985, Light-dependence of phytoplankton photosynthesis in the Antarctic Ocean: Implications for regulating productivity, in: Siegfried, W. R., Condy, P. R. and Laws, R. M. (eds.), Antarctic Nutrient Cycles and Food Webs, Springer-Verlag, Berlin, 60-69.

Tilzer, M. M., Elbraechter, M., Gieskes, W. W., Beese, B., 1986, Light-temperature interactions in the control of photosynthesis in Antarctic phytoplankton, Polar Biol., 5, 105-111.

Trent, J. D., Shanks, A. L., Silver, M. W., 1978, In situ and laboratory measurements on macroscopic aggregates in Monterey Bay, California, Limnol. Oceanogr., 23, 626-635.

Urrere, M. A. Knauer, G. A., 1981, Zooplankton fecal pellet fluxes and vertical transport of particulate organic material in the pelagic environment, J. Plank. Res., 3, 369-387.

Weber, L. H. El-Sayed, S. Z., 1985, Spatial variability of phytoplankton and the distribution and abundance of krill in the Indian sector of the Southern Ocean, in: Siegfried, W. R., Condy, P. R. and Laws, R. M. (eds.), Antarctic Nutrient Cycles and Food Webs, Springer-Verlag, Berlin, 284-293.

Welschmeyer, N. A., Lorenzen, C. J., 1985, Chlorophyll budgets: zooplankton grazing and phytoplankton growth in a temperate fjord and the central Pacific gyres, Limnol. Oceanogr., 30, 1-21.

Wood, A. M., 1979, Chlorophyll a:b ratios in marine planktonic algae, J. Phycol., 15, 330-332. 